Journal of Environmental Sciences (JES)

Institute of Environmental Studies and Research, Ain Shams University

Fouad, Ghada et al.

\title{
AN INTERVENTION STUDY ON KNOWLEDGE OF MALNOURISHED SCHOOL CHILDREN MOTHERS' IN ONE OF EGYPTIAN VILLAGE
}

\author{
Doaa E. Ahmed ${ }^{(1)}$; Hala I. Awadalla ${ }^{(2)}$; Moheb K .El-Rafee ${ }^{(2)}$ \\ and Ammal M. Metwally ${ }^{(3)}$ \\ 1) Community Medicine Research Department, National Research Centre \\ 2) Institute of Environmental Studies and Research, Ain Shams University \\ 3) Faculty of Medicine, Ain Shams
}

\begin{abstract}
Background: School children pass through great physical and mental changes, which affect both their growth and school performance. Childhood malnutrition is a major concern in developing countries. Aim of the study: This study aimed to determine the change in the knowledge of children's mothers at school age in ElothmanyaVillage -El Gharbyia Governorate after an interventional program. Patients and methods: This study targeted two groups: The first group included obese children aged 8 to 15 years old and the second group included underweight children aged 7 to 16 years old using questionnaires, educational tools and model kitchen. Results: In obesity group, mothers' age ranged from 23 to 46 years with mean of $32.3 \pm 5.7$. Most of them were housewives. Most of fathers were workers and farmers in both groups. Attendance of mothers of obese children was as follows; $41.3 \%$ for once, $28.3 \%$ for twice, $17.4 \%$ for 6 times. Mean age of obese children was $10.8 \pm 2.4$. Mean BMI was $27.8 \pm 1.7$ and ranged from 26 to 34 . Knowledge of mothers generally improved with average of $33.3 \%$ regarding obesity. Knowledge regarding obesity complications was found to be the most improved item when comparing it before and after intervention. In underweight group, Mothers' age ranged from 24 to 52 years with mean of $36.7 \pm 6.1$. Attendance of mothers of underweight children was as follows;
\end{abstract}

Vol.(49); Iss.(12); No.(2); Dec..2020

ISSN 1110-0826 
Journal of Environmental Sciences (JES)

Institute of Environmental Studies and Research, Ain Shams University

Doaa E. Ahmed et al.

$29.5 \%$ for once, $32.1 \%$ for twice, $14.1 \%$ for 3 times, $11.5 \%$ for 4 times, $6.4 \%$ for both 5 and 6 times. Mean age of Underweight children was $11 \pm 1.9$. Mean WAZ score was $-1.8 \pm 0.8$ and ranged from -3.09 to -1.02 . Knowledge of mothers generally improved with average of $37.3 \%$ regarding underweight. Knowledge regarding Number of meals was found to be the most improved item when comparing it before and after intervention. Conclusion: These findings indicate that establishing interventional measures to improve knowledge in mothers and body mass index in children, is highly recommended.

Key words: malnutrition, obesity, underweight, knowledge, school children

\section{INTRODUCTION}

The nutritional status of school children is an important indicator of community health. Globally, malnutrition is an underlying or associated cause in at least half of all childhood deaths. Undernutrition alone is responsible for more than one-third of child deaths globally, it accounts for $11 \%$ of the global burden of disease. It is more prevalent in low and lower-middle income countries (Black et al., 2008).

Malnutrition among school age children is a major public health concern. More than 200 million school age children are stunted and underweight; about one billion school children will be growing up by 2020 with impaired physical and mental development (UNICEF, 2011).

While underweight and stunting are major health problems in developing countries, overweight and obesity are emerging due to sedentary life. The prevalence of overweight and obesity among school children ranged from $7 \%$ to $45 \%$ in the Eastern Mediterranean Region (EMR) (Perignon et al., 2014). 
Journal of Environmental Sciences (JES)

Institute of Environmental Studies and Research, Ain Shams University

Fouad, Ghada et al.

Campici et al. (2017) reported that $7.1 \%$ of school children were stunted and $23.1 \%$ were underweight.

World Health Organization (2010), showed that malnutrition was still a major health problem in Egyptian community among different age groups and socio-economic classes. Malnutrition may result from the changes in the demography as well as the lifestyle of the population in Egypt.

In Egypt, malnutrition disorders affect more than $30 \%$ of school children. This problem appears to be largely attributable to poor dietary quality and micronutrient deficiencies, such as iron and Vitamin A (Galal et al., 2005).

El- Zanaty and Way (2009) showed that $5 \%$ of males and $3 \%$ of females aged from 10 - 19 years in Egypt were considered to be underweight, i.e., their BMI values fell below the 5th percentile on the age and sex-specific BMI growth charts.

Progress toward these ends is directly in line with Millennium Development Goals 1 and 2: to halve the proportion of people who suffer from hunger around the world, and to ensure that all children are able to complete a full course of primary school (United Nations, 2008).

The present study aimed at determining knowledge of mothers towards obesity and underweight, among school children in ElothmanyaVillage -El Gharbyia Governorate, Egypt. 
Journal of Environmental Sciences (JES)

Institute of Environmental Studies and Research, Ain Shams University

Doaa E. Ahmed et al.

\section{SUBJECTS AND METHODS}

1. Study type: Community based nutrition education interventional study.

2. Study setting: El Othmanyia village of El Mahala district- Gharbyia governorate.

\section{Study Subjects (Inclusion and exclusion criteria)}

\section{This study targeted two groups:}

- The first group: included obese children aged 8 to 15 years old.

- The second group: included underweight children aged 7 to 16 years old.

a- Subjects Inclusion criteria: All children proved to be malnourished were included in the study: obese and underweight.

b-Subjects exclusion criteria: If the child is under specific curative nutritional program for chronic illness.

4. Sample size: All children aged 7-16 years who proved to be malnourished (obese and underweight) and their mothers were included in the study, 124 children were enrolled in this study as follows:

- 46 malnourished obese children.

- 78 malnourished underweight children.

In addition to inclusion of mothers of all enrolled children in this study.

\section{Study phases:}

1. Phase one: pre-intervention phase

2. Phase two: intervention phase

3. Phase three: post-intervention phase 
Phase one: Pre-intervention phase: This phase for baseline assessment lasted for one month

a) Anthropometric measurements: baseline for weight and height of all malnourished children.

\section{b) Questionnaires:}

- A pilot study was carried out on 20 mothers of children with normal hemoglobin (about $10 \%$ of the study sample) to test the clarity of all questionnaires, estimate the time needed to fulfill each one, as well as to identify any obstacles or problems in data collection. These mothers were not included in the study sample. Results of the pilot study were used in few modifications for the questionnaires

- Specific standardized questionnaires were used to check mothers of all recruited children for knowledge and practices about the problem and its prevention and associated risk habits.

- Baseline 24-hour dietary recall questionnaire; mothers were asked to mention all foods and beverages consumed by their children in the past 24 hours using the 24-hour dietary recall entry sheet by Nelson et al. in Kings College London after its adaptation for Egyptian culture.

- Food frequency questionnaire; The EPIC-Norfolk FFQ that is adapted to the Egyptian culture was used. In addition, it was modified by consortium from the NRC team according to the availability of the food items in the local village market. (http://www.srl.cam.ac.uk/epic/epicffq/ffq.pdf) 
Journal of Environmental Sciences (JES)

Institute of Environmental Studies and Research, Ain Shams University

Doaa E. Ahmed et al.

Phase two: Intervention to improve awareness of children and their mothers using of:

a) This phase was carried out through 6 months for obesity and underweight group (from July 2018 until December 2019). Based on the results from the pre-interventional phase, an implementation plan was set and included the objectives, process indicators, sessions schedule and location followed by an action plan and included specific objectives, tools, approach and percentage of achievement.

b) Educational and multimedia tools appropriate for the malnourished children and their mothers (presentations, posters, educational cards, etc.)

c) Model Kitchen aiming to prepare more nutrient-rich foods and less caloriedense foods with low levels of nutrients every day targeting those showing habits with low levels of nutrients every day.

d) Monitoring of mothers' response to the mentioned approaches using monitoring sheets to recognize mothers' commitment to the recommended given advices to them and to re-tailor recommendations according findings in each case review.

\section{Phase three: Evaluation phase (post intervention):}

\section{a) Anthropometric follow up:}

- Comparing of pre and post anthropometric measurements (WAZ score in underweight group and BMI in obese group).

\section{b) Questionnaires:}

- Follow-up 24-hour dietary recall questionnaire 
- Food frequency questionnaire

- Specific standardized questionnaires to re-check knowledge and practice

\section{RESULTS}

Table (1): Sociodemographic data of studied groups

\begin{tabular}{|l|c|c|}
\hline Sociodemographic data & $\begin{array}{c}\text { Obesity } \\
\text { Description (n=46) } \\
\text { No (\%) }\end{array}$ & $\begin{array}{c}\text { Underweight } \\
\text { Description (n=78) } \\
\text { No (\%) }\end{array}$ \\
\hline Mother's age (years) & $23-46$ & $24-52$ \\
\hline Range & $32.3 \pm 5.7$ & $36.7 \pm 6.1$ \\
\hline Mean $\pm S D$ & $30(28-35)$ & $36(32.25-40)$ \\
\hline Median $(I Q R)$ & & \\
\hline Mother Education & $3(6.5)$ & $8(10.3)$ \\
\hline Illiterate & $4(8.7)$ & $10(12.8)$ \\
\hline Read and Write & $2(4.3)$ & $4(5.1)$ \\
\hline Primary & $3(6.5)$ & $5(6.4)$ \\
\hline Preparatory & $29(63)$ & $42(53.8)$ \\
\hline Secondary & $5(10.9)$ & $9(11.5)$ \\
\hline University & & $70(89.7)$ \\
\hline Mother Occupation & $40(86.9)$ & $4(5.1)$ \\
\hline Housewife & $2(4.3)$ & $2(2.6)$ \\
\hline Farmer & $1(2.2)$ & $2(2.6)$ \\
\hline Worker & $3(6.5)$ & \\
\hline Professional & & $72(92.3)$ \\
\hline Marital status & $43(93.5)$ & $4(5.1)$ \\
\hline Married & $1(2.2)$ & $2(2.6)$ \\
\hline Widow & $2(4.3)$ & \\
\hline Divorced & & \\
\hline
\end{tabular}


Journal of Environmental Sciences (JES)

Institute of Environmental Studies and Research, Ain Shams University

Doaa E. Ahmed et al.

\begin{tabular}{|l|c|c|}
$\begin{array}{l}\text { Cont. Table (1): } \\
\text { Father's education }\end{array}$ & $(\mathbf{n = 4 5 )}$ & $\mathrm{n}=74$ \\
\hline Illiterate & $0(0)$ & $0(0)$ \\
\hline Read and Write & $4(8.8)$ & $5(5.8)$ \\
\hline Primary & $4(8.8)$ & $7(9.5)$ \\
\hline Preparatory & $5(11.1)$ & $8(10.8)$ \\
\hline Secondary & $26(57.8)$ & $47(63.5)$ \\
\hline University & $6(13.3)$ & $7(9.5)$ \\
\hline Father's occupation & $\mathbf{n = 4 5}$ & $\mathrm{n}=74$ \\
\hline Not working & $6(13.3)$ & $16(21.6)$ \\
\hline Farmer & $10(22.2)$ & $17(23)$ \\
\hline Worker & $23(51.1)$ & $36(48.6)$ \\
\hline Employee & $6(13.3)$ & $5(6.8)$ \\
\hline Number of children in the & & $1-5$ \\
\hline house & & $2.7 \pm 1$ \\
\hline Range & $1-5$ & $3(2-3)$ \\
\hline Mean $\pm S D$ & $2.7 \pm 1$ & \\
\hline Median $(I Q R)$ & $3(2-3)$ & \\
\hline Table & $1)$ shows & \\
\hline
\end{tabular}

Table (1) shows that in obesity group, mothers' age ranged from 23 to 46 years with mean of $32.3 \pm 5.7$. Secondary school level was the predominant educational level in both mothers and fathers (63\% and $57.8 \%$ ), only $10.9 \%$ had university education and $6.5 \%$ of mothers were illiterates. Most of them were housewives (86.9\%). Most of fathers were workers (51.1\%).Mean number of siblings was $2.7 \pm 1$.According to underweight group mothers' age ranged from 24 to 52 years with mean of $36.7 \pm 6.1$. Secondary school level was also the predominant educational level in both mothers and fathers (53.8\% and $63.5 \%$ ), only $11.5 \%$ were university level and $10.3 \%$ of mothers were illiterates. Most of them were housewives (89.7\%). Most of mothers 
were married (92.3\%). Most of fathers were workers (48.6\%) and farmers $(23 \%)$. Mean number of kids was $2.7 \pm 1$.

Table (2): attendance among studied children

\begin{tabular}{|c|c|c|}
\hline $\begin{array}{c}\text { Attendance } \\
\text { (number of visits) } \\
\text { of mothers }\end{array}$ & $\begin{array}{c}\text { Obese children } \\
\mathrm{N}=46(\%) \\
\text { No }(\%)\end{array}$ & $\begin{array}{c}\text { underweight children } \\
\text { N= } 78(\%) \\
\text { No }(\%)\end{array}$ \\
\hline 1 & 0 & $1(1.3 \%)$ \\
\hline 2 & $1(2.2 \%)$ & 0 \\
\hline 3 & $2(4.3 \%)$ & $3(3.8 \%)$ \\
\hline 4 & $12(26.7 \%)$ & $14(17.9 \%)$ \\
\hline 5 & $15(33.3 \%)$ & $25(32.1 \%)$ \\
\hline 6 & $16(35.6 \%)$ & $35(44.9 \%)$ \\
\hline
\end{tabular}

Table (2)summarized the frequency of obese children mothers' attendances for educational days. Most of mothers attended 4 times or more $(95.6 \%)$; almost one quarter (26.7\%) attended 4 times, one third (33.3\%) attended 5 times and about one third (35.6\%) for 6 times. While as regards underweight children mothers' attendance, almost three quarters of mothers attended at least 5 times(77\%). Only $5.1 \%$ attended three times or less and $17.9 \%$ for 4 times. 
Table (3): Body mass index, age and gender of the studied children:

\begin{tabular}{|c|c|c|c|c|}
\hline \multirow[b]{2}{*}{ Variable } & \multicolumn{2}{|c|}{ Obese children } & \multicolumn{2}{|c|}{ "Underweight children } \\
\hline & $\begin{array}{c}\mathrm{N}=46 \\
\text { Mean } \pm \\
\text { SD }\end{array}$ & $\begin{array}{l}\text { Range } \\
(\min - \\
\max )\end{array}$ & $\begin{array}{c}\mathbf{N}=78 \\
\text { Mean } \pm \text { SD }\end{array}$ & $\begin{array}{c}\text { Range } \\
(\min -\mathbf{m a x})\end{array}$ \\
\hline Age(in years) & $10.8 \pm 2.4$ & $(8-15)$ & $11 \pm 1.9$ & $(7-16)$ \\
\hline $\begin{array}{l}\text { Body mass index (pre } \\
\text { obese) } \\
\text { Weight age z score(pre } \\
\text { underweight) }\end{array}$ & $27.8 \pm 1.7$ & $(26-34)$ & $-1.8 \pm 0.8$ & $(-3.09--1.02)$ \\
\hline $\begin{array}{l}\text { Body mass index (post } \\
\text { obese) } \\
\text { Weight age z score(post } \\
\text { underweight) }\end{array}$ & $25.7 \pm 2.3$ & $(21.4-34)$ & $-0.2 \pm 0.6$ & $(-1.19--1.37)$ \\
\hline Gender & $\begin{array}{l}\text { Male } \\
\text { Female }\end{array}$ & $\begin{array}{l}(50 \%) \\
3(50 \%)\end{array}$ & $\begin{array}{l}\text { Male } \\
\text { Femal }\end{array}$ & $\begin{array}{l}3(42 \%) \\
45(58 \%)\end{array}$ \\
\hline
\end{tabular}

Table (3) shows that both genders were quite equal (50\% each) among obese children with mean age of $10.8 \pm 2$.4. The BMI mean of obese children was $27.8 \pm 1.7$ (ranged from 26 to 34 )pre interventional and improved after intervention to be $25.7 \pm 2.3$ (ranged from $21.4-34$ ). On the other side, that underweight female gender was more (58\%) comparing to males (42\%), mean age of underweight children is $11 \pm 1.9$, their mean WAZ score was $1.8 \pm 0.8$ (ranged from -3.09 to -1.02 ) pre interventional and improved after intervention to be $-0.2 \pm 0.6$ (ranged from $-1.19--1.37$ ). 
Table (4): Mothers' knowledge regarding obesity among studied obese children

\begin{tabular}{|c|c|c|c|c|c|c|c|c|}
\hline \multirow{2}{*}{$\begin{array}{c}\text { Ser } \\
.\end{array}$} & \multirow{2}{*}{ Knowledge Item } & \multicolumn{2}{|c|}{$\begin{array}{c}\text { Average } \\
\text { Score } \\
\end{array}$} & \multicolumn{2}{|c|}{$\begin{array}{c}\% \\
\text { Knowledge } \\
\end{array}$} & \multirow{2}{*}{$\begin{array}{c}\text { P value } \\
(\%)\end{array}$} & \multicolumn{2}{|c|}{ Change } \\
\hline & & $\begin{array}{c}\text { Befor } \\
e\end{array}$ & After & Before & After & & $\begin{array}{c}\text { Valu } \\
e\end{array}$ & $\begin{array}{c}\text { Sig } \\
n\end{array}$ \\
\hline $\mathbf{1}$ & Meaning of Obesity & 3.5 & 5.7 & 34.8 & 56.5 & 0.038 & 21.7 & + \\
\hline 2 & Diagnosis of Obesity & 9.5 & 10.0 & 95.5 & 100.0 & $\begin{array}{c}0.147 \\
8\end{array}$ & 4.5 & + \\
\hline 3 & Knowledge about Bad habits & 3.7 & 8.2 & 37.0 & 82.2 & $\begin{array}{c}< \\
0.000 \\
1\end{array}$ & 45.2 & + \\
\hline 4 & Complications & 2.5 & 9.5 & 25.0 & 95.4 & $\begin{array}{c}< \\
0.000 \\
1\end{array}$ & 70.4 & + \\
\hline 5 & Risk Factors & 9.5 & 10.0 & 95.0 & 100.0 & 0.148 & 5.0 & + \\
\hline 6 & $\begin{array}{l}\text { Knowledge about Healthy } \\
\text { habits }\end{array}$ & 5.0 & 9.5 & 25.1 & 47.4 & 0.027 & 22.3 & + \\
\hline 7 & Associated Drugs & 7.9 & 9.0 & 79.2 & 90.3 & 0.141 & 11.1 & + \\
\hline 8 & Number of meals & 9.0 & 10.0 & 90.0 & 100.0 & 0.029 & 10.0 & + \\
\hline 9 & Psychological support & 3.5 & 5.1 & 35.2 & 51.3 & 0.121 & 16.1 & + \\
\hline Ove & & 54.1 & 77 & 33.0 & 70.3 & 0.004 & 37.3 & + \\
\hline
\end{tabular}

Table (4) showed that knowledge of mothers was improved post interventional in most items with statistically significant positive change $(\mathrm{p}<0.05)$. The overall knowledge scores of mothers about obesity changed from $33.0 \%$ to $70.3 \%$ with highly statistically significant difference ( $\mathrm{p}<0.01)$. Knowledge about bad habits and knowledge of obesity complications found to be the most improved items before and after intervention with highly statistically significant difference $(p<0.01)$ (from 
Doaa E. Ahmed et al.

$37.0 \%$ to $82.2 \%$ and from $25.0 \%$ to $95.4 \%$ respectively), knowledge about related healthy habits to obesity, knowledge of number of meals and knowledge regarding meaning of obesity improved significantly $(\mathrm{p}<0.05)$ (from $25.1 \%$ to $47.4 \%$, from 90.0 to 100.0 and from $34.8 \%$ to $56.5 \%$ respectively).Knowledge regarding psychological support, Knowledge for risk factors. Knowledge of associated drugs and Knowledge how to diagnose obesity improved however with no statistically significant difference $(\mathrm{p}>0.05)$.

Table (5): Mothers' knowledge regarding underweight among studied underweight children

\begin{tabular}{|c|c|c|c|c|c|c|c|c|}
\hline \multirow[b]{2}{*}{ Ser. } & \multirow[b]{2}{*}{ Item } & \multicolumn{2}{|c|}{ Average Score } & \multicolumn{2}{|c|}{ \% Knowledge } & \multirow[b]{2}{*}{$P$ value } & \multicolumn{2}{|c|}{ Absolute Change } \\
\hline & & Before & After & Before & After & & $\begin{array}{c}\text { Value } \\
\%\end{array}$ & Sign \\
\hline 1 & Related Bad Habits & 5.0 & 8.7 & 49.6 & 86.8 & 0.0001 & 37.1 & + \\
\hline 2 & Complication & 5.5 & 9.4 & 55.4 & 94.0 & $<0.0001$ & 38.7 & + \\
\hline 3 & Risk Factors & 5.6 & 8.7 & 55.8 & 87.1 & $<0.0001$ & 31.3 & + \\
\hline 4 & Related Diseases & 3.8 & 7.0 & 37.8 & 69.6 & 0.0001 & 31.9 & + \\
\hline 5 & Good Habits & 4.0 & 7.1 & 39.8 & 71.3 & 0.0001 & 31.4 & + \\
\hline 6 & Eating Manner & 4.4 & 7.6 & 44.0 & 75.6 & 0.0001 & 31.5 & + \\
\hline 7 & $\begin{array}{l}\text { Encouraging } \\
\text { Environment for } \\
\text { Eating }\end{array}$ & 3.7 & 7.3 & 36.9 & 73.2 & $<0.0001$ & 36.3 & + \\
\hline 8 & Number of Meals & 3.2 & 9.3 & 32.1 & 92.9 & $<0.0001$ & 60.7 & + \\
\hline 9 & Bread Portions & 4.5 & 9.1 & 44.6 & 91.1 & $<0.0001$ & 46.4 & + \\
\hline 10 & Rice Portions & 4.1 & 9.1 & 41.1 & 91.1 & $<0.0001$ & 50.0 & + \\
\hline 11 & Macaroni Portions & 3.6 & 9.3 & 35.7 & 92.9 & $<0.0001$ & 57.1 & + \\
\hline 12 & Vegetable Portions & 6.3 & 9.8 & 62.5 & 98.2 & $<0.0001$ & 35.7 & + \\
\hline 13 & Fruits Portions & 5.7 & 9.5 & 57.1 & 94.6 & $<0.0001$ & 37.5 & + \\
\hline 14 & Milk Portions & 5.5 & 9.1 & 55.4 & 91.1 & $<0.0001$ & 35.7 & + \\
\hline 15 & $\begin{array}{l}\text { Indications } \\
\text { Visiting a Doctor }\end{array}$ & 4.3 & 7.5 & 42.9 & 75.0 & $<0.0001$ & 32.1 & + \\
\hline 16 & $\begin{array}{l}\text { Needed Factors to } \\
\text { Manage }\end{array}$ & 2.9 & 6.7 & 28.6 & 66.8 & $<0.0001$ & 38.2 & + \\
\hline \multicolumn{2}{|c|}{ Average Score } & 86.4 & 153.5 & 48.0 & 85.3 & $<0.0001$ & 37.3 & + \\
\hline
\end{tabular}


Table (5) showes that Knowledge of mothers of underweight children regarding underweight was improved with statistically highly significant positive change $(\mathbf{p}<0.01)$ in all items; Knowledge of mothers generally improved from 48 to 85.3 , most of assessed items (15 out of 17) found to be improved, knowledge regarding number of meals found to be the most improved item when comparing it before and after intervention (from 32.1\% to $92.9 \%$ ), then knowledge about macaroni, rice and bread portions also improved from (35.7\% to $92.9 \%)$, (41.1\% to $91.1 \%)$ and $(44.6 \%$ to $91.1 \%)$ correspondingly, then knowledge about complications of underweight also improved from $55.4 \%$ to $94 \%$, then knowledge regarding Needed Factors to Manage also improved from $28.6 \%$ to $66.8 \%$ but still in need to more improvement and meaning and diagnosis of underweight found to be optimum (100\%) before and after intervention. 
Doaa E. Ahmed et al.

Table (6): Correlations of age, education and knowledge score among obese children:

\begin{tabular}{|c|c|c|c|c|c|c|c|c|}
\hline & & Child age & $\begin{array}{c}\begin{array}{c}\text { Mother } \\
\text { age }\end{array} \\
\end{array}$ & $\begin{array}{c}\text { Mother } \\
\text { education }\end{array}$ & $\begin{array}{c}\text { Pre } \\
\text { knowledge }\end{array}$ & $\begin{array}{c}\text { Post } \\
\text { knowledge }\end{array}$ & $\begin{array}{c}\text { Knowledge } \\
\text { change }\end{array}$ & Attendance \\
\hline \multirow{2}{*}{$\begin{array}{l}\text { Child } \\
\text { age }\end{array}$} & $r$ & 1 & & & & & & \\
\hline & P value & & & & & & & \\
\hline \multirow{2}{*}{$\begin{array}{l}\text { Mother } \\
\text { age }\end{array}$} & $r$ & & 1 & & & & & \\
\hline & P value & & & & & & & \\
\hline \multirow{2}{*}{$\begin{array}{l}\text { Mother } \\
\text { education }\end{array}$} & $r$ & & .011 & 1 & & & & \\
\hline & P value & & .944 & & & & & \\
\hline \multirow{2}{*}{$\begin{array}{c}\text { Pre } \\
\text { knowledge }\end{array}$} & $r$ & $-.088-$ & $.356^{*}$ & .111 & 1 & & & \\
\hline & P value & .561 & .015 & .461 & & & & \\
\hline \multirow{2}{*}{$\begin{array}{c}\text { Post } \\
\text { knowledge }\end{array}$} & $r$ & $-.223-$ & .206 & .030 & $.498 * *$ & 1 & & \\
\hline & P value & .137 & .169 & .841 & .000 & & & \\
\hline \multirow{2}{*}{$\begin{array}{c}\text { Knowledge } \\
\text { change }\end{array}$} & $r$ & $-.103-$ & $-.201-$ & .203 & -.637 & $.350 *$ & 1 & \\
\hline & P value & .496 & .180 & .176 & .000 & .017 & & \\
\hline \multirow{2}{*}{ Attendance } & $r$ & -.217 & $-.089-$ & .071 & $-.304-*$ & $-.217-$ & .149 & 1 \\
\hline & P value & .148 & .556 & .637 & .040 & .148 & .323 & \\
\hline
\end{tabular}

Table (6) shows correlations related to obese group regarding the following variables; child age, mother age, mother education, pre knowledge, post knowledge, positive knowledge change, frequency of attendance, all individual correlation between each variable found to be non-significant linear correlation except for; knowledge prior intervention and positive knowledge change it was invers moderate correlation i.e. the lower score prior intervention get more benefit (positive change of knowledge score) from the intervention. Also mother age found to be positively weak correlated $\mathrm{r}=0.36(\mathrm{p}=0.015)$ with their knowledge prior intervention, pre knowledge was positive moderately correlated with post knowledge $r=0.498(\mathrm{p}<0.001)$, also 
pre knowledge was inverse strongly correlated with knowledge change r=$0.64(\mathrm{p}<0.001)$ and pre knowledge was inverse weakly correlated with frequency of attendance $r=-0.3(p=0.04)$ i.e. they were in greater need to learn.

Table (7) Correlations of age, education and knowledge score among underweight children:

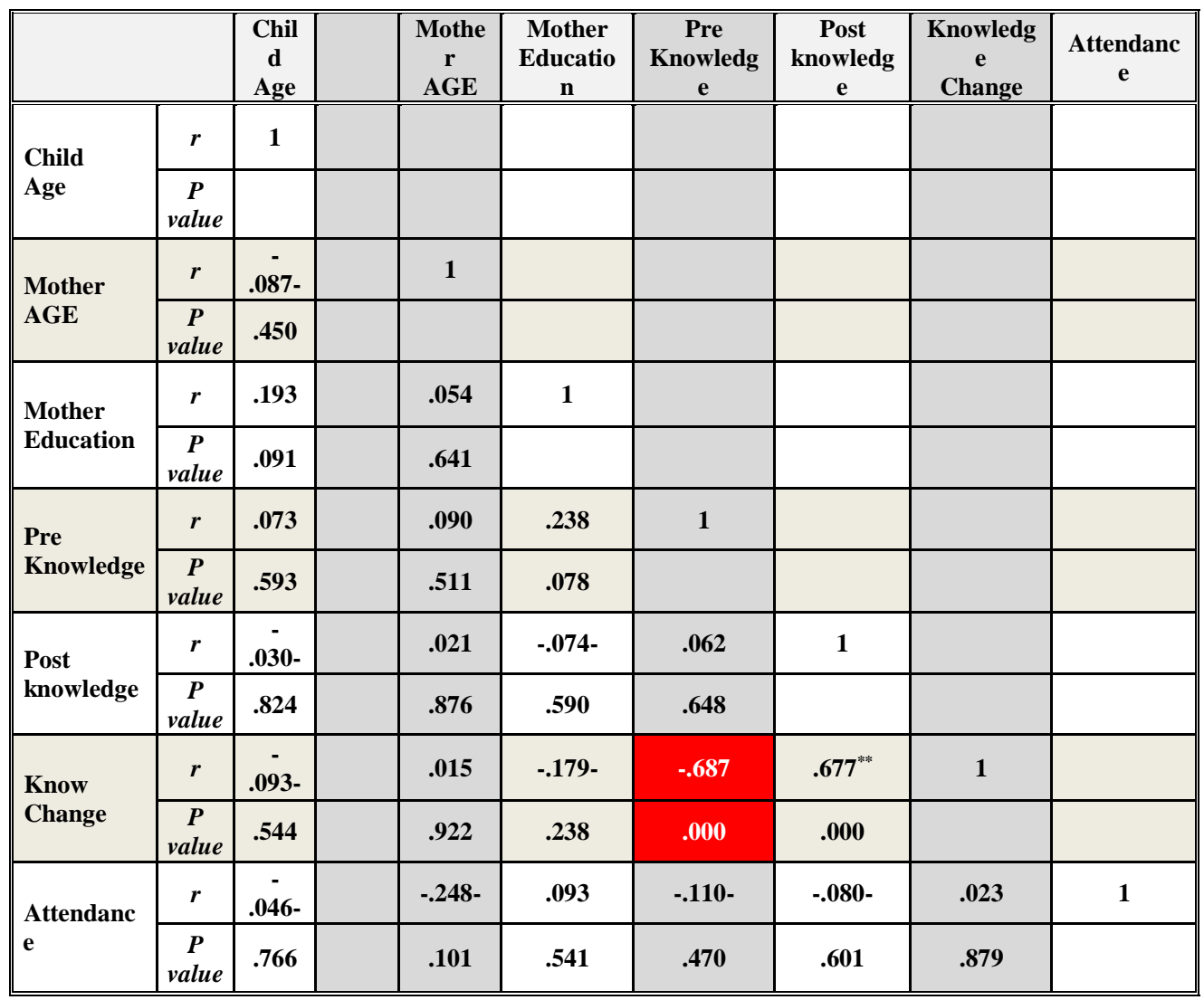


Journal of Environmental Sciences (JES)

Institute of Environmental Studies and Research, Ain Shams University

Doaa E. Ahmed et al.

Table (7) shows correlations related to underweight group regarding the following variables; child age, mother age, mother education, pre knowledge, post knowledge, positive knowledge change, frequency of attendance, all individual correlation between each variable found to be non-significant linear correlation except for; knowledge prior intervention and positive knowledge change it was invers strong correlation $r=-0.69(p<0.001)$ i.e. the lower score prior intervention get more benefit (positive change of knowledge score) from the intervention.

\section{DISCUSSION}

Childhood overweight and obesity, an emerging public health problem in developing countries, has been linked with the increasing westernization of societies and associated changes in lifestyle. Many developing nations are in a state of nutritional transition, in which there is a persistently high level of under-nutrition in the face of emerging overweight and obesity (Musa et al., 2012).

The prevalence of childhood has ranged from $0 \%$ to $26.7 \%$ in different age groups, depending on the methods of assessment used. Examples of different methodologies are measurement of body mass index versus bioelectrical impedance versus waist circumference (Intiful et al., 2013).

The complications of overweight and obesity could occur during childhood and adolescence and persist into adulthood, with increased risk of morbidity and mortality later in life. These complications include the 
Journal of Environmental Sciences (JES)

Institute of Environmental Studies and Research, Ain Shams University

Fouad, Ghada et al.

development of elevated blood pressure with its attendant risks of long-term cardiovascular morbidity and early death. On account of these complications, the prevention and treatment of overweight and obesity in childhood have emerged as an important focus of paediatric research and clinical care (Gahagan, 2011).

Environmental and genetic factors have been implicated in the prevalence of overweight and obesity, although some inconsistencies in the effects have been reported. Among children especially in developing countries, being born into a family with a high income, higher levels of maternal education, low levels of physical activity, female gender and race are major risk factors. However, prenatal factors such as maternal gestational diabetes and fetal nutritional status are also important (Ejikeand Ugwu, 2011).

The pattern of physical activity, television viewing and family socioeconomic status could be interrelated but few studies in Nigeria have looked at the impact of presence or absence of television in the child's sleeping room and number of hours spent per day on the screen on the prevalence of overweight and obesity (Ogden et al., 2006).

The early identification of modifiable risk factors in childhood could provide an avenue for intervention in curbing the increasing prevalence of overweight and obesity. Overweight and obesity are more amenable to treatment in early life and early intervention could help to reduce both the

Vol.(49); Iss.(12); No.(2); Dec..2020 
Journal of Environmental Sciences (JES)

Institute of Environmental Studies and Research, Ain Shams University

Doaa E. Ahmed et al.

short-term and long-term consequences of overweight and obesity, as well as break the tracking into adolescence and adulthood (Janjua et al., 2012).

This study provides anthropometric data (weight and height) on the nutritional status in a group of school children aged $7-16$ years in Elothmanya Village, El Gharbyia Governarate, Egypt, the study included two groups: The first group obese children aged 8 to 15 years old and the second group underweight children aged 7 to 16 years old.13\% of the whole sample were underweight and 7.6 were obese.

Abdelaziz et al. (2015) determined the nutritional status and dietary habits of 1100 school children. They illustrated students' nutritional status in comparisons to the WHO reference growth curves. $10 \%$ of the students less than 10 years were underweight, $53.2 \%$ of the whole sample were stunted, whereas BMI z-score; <-2SD and >+2SD was 2.8\% (underweight) and $34.4 \%$ (obese) respectively.

In obesity group, Secondary school level was the predominant educational level in both mothers and fathers (63\% and $57.8 \%), 6.5 \%$ of mothers were illiterates and only $10.9 \%$ were university level. Most of them were housewives $(86.9 \%)$. Most of fathers were workers $(51.1 \%)$ and farmers (22.2\%). Mean number of kids was 2.7 \pm 1 . Abdelaziz et al. (2015) found that the majority of the mothers were illiterate and not working; 1086 (98.7\%) and $1092(99.3 \%)$ respectively. One thousand and seventy (97.3\%) fathers were illiterate and working as farmers. 
Journal of Environmental Sciences (JES)

Institute of Environmental Studies and Research, Ain Shams University

Fouad, Ghada et al.

Frequency of obese children mothers' attendance for educational days as follows; almost most (95.6\%) of mothers attended at least 4 times, (almost one quarter (26.7\%)for 4 times, one third (33.3\%) for 5 times and almost one third $(35.6 \%)$ for 6 times.

Both genders were quite equal (50\% per each gender). Mean age of obese child was $10.8 \pm 2.4$.

El-Zanaty and Way (2009) reported that boys tended to be more obese in the age group from 10 - 14 years in comparison to girls, this could have been due to the effect of extension of cultural preference for boys.

Gharib and Rasheed (2009) found that ages of students ranged from 6 to 18 years, with a mean of $12 \pm 3.6$ years. The median heights of Bahraini boys and girls aged 6 to 7 years were close to the $50^{\text {th }}$ percentile of the WHO standards or higher; thereafter, median heights were closer to the 25th percentile up to age 18 years in boys and 13 years in girls. In late adolescence, the median height of girls showed a decline to the 15th percentile. The median BMI remained close to the WHO $50^{\text {th }}$ percentile at all ages in boys and up to age 12 years in girls. In girls, BMI increased to between the 50th and75th percentile during adolescence.

Cândido et al. (2011) assessed the predictive abilities of anthropometric measurements compared to those of the commonly used methods, such as BMI, to correctly identify multiethnic schoolchildren with high fat mass, using the tetrapolar bioelectrical impedance technique (BIA-T) as the 
Journal of Environmental Sciences (JES)

Institute of Environmental Studies and Research, Ain Shams University

Doaa E. Ahmed et al.

reference method. The total sample $(\mathrm{n}=788)$ was comprised $52.3 \%$ girls and $47.7 \%$ boys, all aged 6-15 years. The prevalence of overweight and obesity was $12.2 \%$ and $5.8 \%$ in girls and $10.6 \%$ and $2.9 \%$ in boys, respectively.

Abdelaziz et al. (2015) determined the nutritional status and dietary habits of 1100 school children with mean age $10.18( \pm 2.5)$ years. Of these students, 945 (85.9\%) were girls, and 155 (14.1\%) boys. Most of the students $891(81 \%)$ have large family size equal to or more than five persons.

Adetunji et al. (2019) determined the socio-demographic factors associated with overweight and obesity among primary school children in semi-urban areas. Fifty-eight pupils (4.9\%) had overweight and obesity while $41(3.5 \%)$ had under-nutrition (being thin/severely thin) and $1088(91.6 \%)$ were of normal nutritional status. Among those with overweight and obesity, $41(3.5 \%)$ were overweight and $17(1.4 \%)$ obese.

Karimy et al. (2019) determined the knowledge, attitude, and practices (KAP) of Iranian mothers towards childhood overweight and obesity. According to BMI results, most of the children $(n=379)$ were in the normal range, while 53 children (9.2\%) were OB. The prevalence of OB was $11.5 \%$ in boys and $7 \%$ in girls, and this difference was statistically significant. A total of 271 mothers under study were obese.

Knowledge of mothers generally improved with average of $33.3 \%$ regarding obesity. All of assessed items were found to be improved. Knowledge regarding obesity complications was found to be the most improved item when comparing it before and after intervention (from $25 \%$ to 
Journal of Environmental Sciences (JES)

Institute of Environmental Studies and Research, Ain Shams University

Fouad, Ghada et al.

95.4\%), then knowledge about related bad habits to obesity also improved from $37 \%$ to $82.2 \%$. then knowledge about related healthy habits to obesity also improved from $25.1 \%$ to $47.4 \%$, then knowledge regarding meaning of obesity also improved from $34.8 \%$ to $56.5 \%$, then knowledge regarding psychologic support to obese child also improved from $35.2 \%$ to $51.3 \%$. There was slight improvement for risk factors and diagnosis of obesity.

Karimy et al. (2019) found that the mean score of $15.8 \pm 3.4$ out of 20 received by mothers indicated that the population under study had relatively good knowledge. For example, most of the mothers knew about the factors affecting obesity such as inappropriate feeding, fast foods (79\%), inactivity (76\%), and genetics (68\%). Also, 81\% knew about the effect of childhood obesity on adulthood diabetes and hypertension. A total of $46 \%$ of mothers considered industrial fruit juice as a suitable substitute for natural fruit. The independent $t$ test did not show any significant difference in the mean scores for knowledge between mothers with obese children and those with normalweight children. They identified the importance of educating mothers to change of lifestyle (eating and physical activity habits) towards weight control in their children.

Underweight is most commonly used as a composite indicator to reflect both acute and chronic undernutrition (Bose et al.,2008). The results of the present study indicated that mothers' age ranged from 24 to 52 years with mean of $36.7 \pm 6.1$. Secondary school level was the predominant educational 
Journal of Environmental Sciences (JES)

Institute of Environmental Studies and Research, Ain Shams University

Doaa E. Ahmed et al.

level in both mothers and fathers (53.8\% and $63.5 \%), 10.3 \%$ of mothers were illiterates and only $11.5 \%$ were university level. Most of them were housewives (89.7\%). Most of fathers were workers (48.6\%) and farmers (23\%). Mean number of kids was $2.7 \pm 1$.

Hassan et al. (2018) assessed the nutritional status and calculate the prevalence of malnutrition among a group of school children living in the rural area of Manshit El Gamal village in Tamia district of Fayoum Governorate Egypt. More than half of the mothers of the studied sample (67.3\%) were below secondary schooling, and almost all of them were housewives, (89.4\%). For the fathers, nearly $40 \%$ of them had formal education at or beyond secondary school, and $45.4 \%$ had irregular work. The majority of participants, (55.6\%) were members of large family size (more than 5) with nearly half of participants classified in the low socioeconomic level.

Low maternal education was a major determinant of malnutrition. Malnourished children of illiterate mothers and fathers were at risk of being malnourished in comparison to normal children. Expectedly, as the level of education of the mother increases, so do her finances and her contribution to the total family income. Thus, educating women would be a useful step in the reduction of the prevalence of poor childhood nutrition, especially stunting (Pongou,2013).

These results are also in agreement with Adegun et al. (2013) among the same age group who reported that the mothers' educational level is as 
Journal of Environmental Sciences (JES)

Institute of Environmental Studies and Research, Ain Shams University

Fouad, Ghada et al.

important underlying determinants that directly or indirectly cause malnutrition among children.

Underweight females were $57.7 \%$ and males were $42.3 \%$. Mean age of underweight children was $11 \pm 1.9$.

El-Zanaty and Way (2009) reported that 5 percent of males and 3 percent of females aged from 10 - 19 years in Egypt, were considered to be underweight, i.e., their BMI values fell below the 5th percentile on the age and sex-specific BMI growth charts. Fetuga et al. (2011) reported the prevalence of underweight occurring more in boys than girls. Hassan et al. (2018) found that the study participants' age ranged from 6 years up to 17 years old with $58.3 \%$ males. No significant difference detected between males and females regarding age distribution.

Knowledge of mothers generally improved with average of $37.3 \%$ regarding underweight. Most of assessed items (15 out of 17) were found to be improved. Knowledge regarding Number of meals found to be the most improved item when comparing it before and after intervention (from $32.1 \%$ to $92.9 \%$ ), then knowledge about macaroni, rice and bread portions also improved from (35.7\% to $92.9 \%),(41.1 \%$ to $91.1 \%)$ and $(44.6 \%$ to $91.1 \%)$ correspondingly, then knowledge about complications of underweight also improved from $55.4 \%$ to $94 \%$, then knowledge regarding Needed Factors to Manage also improved from $28.6 \%$ to $66.8 \%$ but still in need to more 
Journal of Environmental Sciences (JES)

Institute of Environmental Studies and Research, Ain Shams University

Doaa E. Ahmed et al.

improvement. Meaning and diagnosis of underweight were found to be optimum (100\%) before and after intervention.

Aljohani and Aljohani (2020) investigated the knowledge of mothers about malnutrition and maternal associated factors. They concluded that there was an acceptable level of knowledge of mothers regarding the malnutrition of children; however, this knowledge should be increased. Age and educational level of mothers, monthly income, number of children, breastfeeding, and source of knowledge were important factors that influenced the knowledge of mothers.

The findings of this study showed that the contribution of the milk/milk products, vegetables, fruits food groups fell far below the recommendation of food based dietary guidelines (World Food Programme, 2010). However, the findings are similar to a study done in the Eastern Mediterranean Region [EMR] (WorldHealthOrganization,2010), which reported a relatively low consumption of vegetables and fruits in most of the developing countries and also another one done in Kenya (Ministry of Health $(\mathrm{MoH})$ and United Nations International Children's Education Fund (UNICEF),2011).

Consumption of animal source foods was found to be associated with a decreased risk of stunting and underweight (World Food Programme,2004). A study that was conducted by Dror and Allen (2011) reported that consuming animal source foods not only decreased stunting but also improved other anthropometric indices toward the reduction of morbidity and mortality among undernourished children. 
Abdelaziz et al. (2015) showed the association between malnutrition and various socioeconomic factors. The prevalence of malnutrition was significantly higher among underweight and obese students aged above 10 years, of illiterate mothers and fathers. Also, a significant higher percentage of large family size was detected among malnourished children compared to those of normal weight. As regards food consumption and students' nutritional status aged more than 10 years, statistically significant differences were found between students' HAZ and those consuming; $\geq 3$ or $<3$ times regarding the daily consumption of milk/milk products, vegetables, fruits, candies and cereals (grains, flour and rice). Another significant difference was detected between students' BMI z-score and those consuming; $\geq 2$ or $<2$ times regarding weekly consumption of red meat. They concluded that child's nutritional status is strongly associated with the literacy of both parents and family size. The prevalence of malnutrition can be reduced by implementation of school intervention programs for the socioeconomic development.

Results of this study also showed insignificant correlation between mothers' education level and knowledge percent score before the intervention and after the nutritional educational intervention. This may explain the strength of the nutritional educational sessions in improving the knowledge concerning malnutrition problems regardless of education level of the mothers. However, these results don't match with Jafari et al. whose results showed significant and 
Journal of Environmental Sciences (JES)

Institute of Environmental Studies and Research, Ain Shams University

Doaa E. Ahmed et al.

positive correlation between mothers' educational level and knowledge improvement after the intervention $(\mathrm{r}=0.169, \mathrm{P}<0.002)$.

Sarika (2016) found that knowledge was associated with the educational status of mothers, Nath and Kanniammal (2017) reported association between knowledge and educational status, as well as a socioeconomic class. It was found that knowledge increased with number of children and level of education.

Bel- Serrat et al. (2018) investigated whether school sociodemographic indicators were associated with weight status in primary schoolchildren. They concluded that school socioeconomic status was a strong determinant of overweight and obesity in schoolchildren. Adetunji et al. (2019) concluded that overweight and obesity among primary school pupils in semi-urban areas is associated with female gender, attendance at private schools and higher socioeconomic status families.

Aljohani and Aljohani (2020) concluded that there was an acceptable level of knowledge of mothers regarding malnutrition of children, and there were several factors that affected the level of knowledge, including age and educational level of mothers, monthly income, number of children, breastfeeding, and source of knowledge.

In this regard, the nutritional status of children in the developing countries should be emphasized not only for the improvement of health of children in the coming generation, but also for the overall development of the concerned region in the future. 
Journal of Environmental Sciences (JES)

Institute of Environmental Studies and Research, Ain Shams University

Fouad, Ghada et al.

\section{CONCLUSION AND RECOMMENDATIONS}

Malnutrition among students is a major public health problem in Egypt. Besides poverty, there are other factors that directly or indirectly affect the nutritional status of students. Literacy and social status of the family are key factors contributing to malnutrition in students. The present study highlights the prevalence of malnutrition among school going students in El OthmanyaVillage, El Gharbyia Governarate in Egypt and the prevalence can be reduced by increasing awareness in mother regarding the nutritional intake of the student.

There was an acceptable level of knowledge of mothers regarding the malnutrition of children; however, this knowledge should be increased, as there were lacking in some points. monthly income, breastfeeding, and source of knowledge were important factors that influenced the knowledge of mothers.

There is a great need to focus the attention of policy-makers on the nutritional status of students as one of the main indicators for implementation of school intervention programs and as a precondition for the socioeconomic development in the long term.

It seems necessary to develop interventions to improve and modify nutritional functions and create appropriate physical activity habits in children in order to change the beliefs and lifestyles of families with the aim of preventing and overcoming problems such as obesity in children. 


\section{REFERENCES}

Abdelaziz SB; Youssef MRL; Sedrak AS and Labib JR. (2015): Nutritional status and dietary habits of school children in Beni- Suef Governorate, Egypt. Food and Nutrition Sciences; 6: 54-63.

Adegun; J.A.; Ajayi-Vincent; O.B. and Alebiosu; E.O. (2013): Differences in the Nutritional Status of Young School Children from Public and Private Owned Primary Schools in Ekiti State, Nigeria. European Scientific Journa; 9.

Adetunji AE; Adeniran KA; Olomu SC; Odike AI; Ewah- Odiase RO, Omoike IU; et al. (2019): Socio- demographic factors associated with overweight and obesity among primary school children in semi-urban areas of mid-western Nigeria. PLoS ONE; 14(4): $\mathrm{e} 0214570$.

Aljohani AA and Aljohani MA. (2020): The knowledge of mothers about children malnutrition and associated factors. International Journal of Medicine in Developing Countries,4 (1):007-011.

Bel- Serrat S; Heinen MM; Mehegan J; O'Biren S; Eldin N; Murrin CM and Kelleher CC. (2018): School sociodemographic characteristics and obesity in schoolchildren: Does the obesity definition matter? BMC Public Health; 18: 337.

Black; R.E.; Allen, L.H.; Bhutta; Z.A. (2008): Maternal and Child Undernutrition: Global and Regional Exposures and Health Consequences. Lancet; 371: 243-260.

Bose; K.; Bisai; S.; Chakraborty; J.; Dutta; N. and Banerjee; P. (2008): Extreme Levels of Underweight and Stunting among PreAdolescent Children of Low Socioeconomic Class from Madhyamgram and Barasat, West Bengal, India. Collegium Antropologicum; 32: 73-77. 
Campici SC; Cherian AM; Bhuta ZA. (2017): Perspective on the epidemiology of stunting between 1990 and 2015. Horm Res Paediatr; 88: 70-8.

Cândido APC; Freitas SN and Machado- Coelho GLL. (2011): Anthropometric measurements and obesity diagnosis in schoolchildren. Acta Paediatrica,100 (9):e120-4.

Dror; D.K. and Allen; L.H. (2011): The Importance of Milk and Other Animal-Source Foods for Children in Low-Income Countries. Food and Nutrition Bulletin; 32: 227-243.

Ejike CE and Ugwu C. (2011): Hyperbolic relationship between blood pressure and body mass index in a Nigerian adolescent population. http://www.webmedcentral.com.

El- Zanaty; F. and Way; A. (2009): Egypt Demographic and Health Survey 2008. Demographic and Health Surveys, Ministry of Health, Cairo.

Fetuga; M.B.; Ogunlesi, T.A.; Adekanmbi; A.F. and Alabi; A.D. (2011): Growth Pattern of Schoolchildren in Sagamu, Nigeria Using the CDC Standards and WHO Standards 2007. Indian Pediatrics; 48: 523-528.

Gahagan S. (2011): Overweight and Obesity. In: Kliegman RM, Stanton BF, Geme JW, Schor NF, Behrman RE, editors. Nelson Textbook of Paediatrics. 19th edition. Philadephia, Saunders; 179-87.

Galal, O.M., Ismail, I., Gohar, A.S. and Foster, Z (2005): Schoolteachers' Awareness about Scholastic Performance and Nutritional Status of Egyptian Schoolchildren. Food and Nutrition Bulletin; 26: S275-S280.

Gharib NM and Rasheed P. (2009): Anthropometry and body composition of school children in Bahrain. Ann Saudi Med; 29(4): 258-269. 
Journal of Environmental Sciences (JES)

Institute of Environmental Studies and Research, Ain Shams University

Doaa E. Ahmed et al.

Hassan SK; Abdelwahed WY and Eldessouki R. (2018): Nutritional status and some sociodemographic and lifestyle characteristics among a group of rural school children in Fayoum Governorate, Egypt. The Egyptian Journal of Community medicine; 36 (2). 
Intiful FZ; Ogyiri L; Asante M; Mensah AA; Steele-Dsdzie RK; Boateng L. (2013): Nutritional status of boarding and non-boarding children in selected schools in the Accra metropolis. Journal of Biology, Agriculture and Healthcare; 3: 156-162.

Jafari F; Kholdi N; Karimi A (2012): Effectiveness of an educational program on mothers' knowledge about iron deficiency anemia. Summer; 13 (4): 56.

Janjua N.Z; Mahmood B, M. Islam A; Goldenberg R.L. (2012): Maternal and Early Childhood Risk Factors for Overweight and Obesity among Low-Income Predominantly Black Children at Age Five Years: A Prospective Cohort Study. Journal of Obesity.

Karimy M; Armoon B; Fayazi N and Koohestani HR. (2019): A study on the knowledge, attitude, and practices of Iranian mothers towards childhood obesity. Obes Facts; 12: 669-677.

Ministry of Health $(\mathrm{MoH})$ and United Nations International Children's Education Fund (UNICEF). (2001): National Micronutrient Survey Report 1999. Anemia and Status of Iron, Vitamin A and Zinc in Kenya. UNICEF; 93.

Musa DI; Toriola AL; Monyeki MA; Lawal B. (2012): Prevalence of childhood and adolescent overweight and obesity in Benue State, Nigeria. Tropical Medicine \& International Health; 17: 1369-75.

Nath LR; Kanniammal C. (2017): Knowledge and practice of mothers regarding the prevention and management of malnutrition among preschool children: A cross sectional survey. Int J Pharm Clin Res; 9(5): 410-2.

Nelson M; Erens B; Bates B; Church S; Boshier L (1994): 24-hour recall instructions. Kings College London. Available from: 
Journal of Environmental Sciences (JES)

Institute of Environmental Studies and Research, Ain Shams University

Doaa E. Ahmed et al.

http://dapa-toolkit.mrc.ac.uk/documents/en/24h/24hr

Instructions_LIDNS.pdf. Last accessed October 2018.

https://www.hemocue.com/en/solutions/hematology/hemocue-hb-201plussystem

Ogden CL; Carroll MD; Curtin LR. (2006): Prevalence of overweight and obesity in the United States 1999-2004. JAMA.; 295: 1549-1555.

Olamoyegun MA; Oluyombo R; Iwuala SO; Asaolu SO. (2016): Epidemiology and patterns of hypertension in semi-urban communities, south-western Nigeria. Cardiovasc J Afr; 27: 356360 .

Perignon M; Marion F; Khov K; Kurt B; Megan P; Sisokhom S; et al. (2014): Stunting poor iron status and parasite infection are significant risk factorsfor lower cognitive performance in Cambodian schoolaged children. PLoS One; 11(9): 1-11.

Pongou; R. (2013): Why Is Infant Mortality Higher in Boys than in Girls? A New Hypothesis Based on Preconception Environment and Evidence from a Large Sample of Twins. Demography; 50: 445446.

Sarika Y. (2016): Knowledge and practice of mothers regarding prevention of PEM among mothers of under five children. IOSR J Nurs Health Sci.;4 (4):27-35.

Sayyari AA; Abdollahi Z; Ziaodini H; Olang B; Fallah H; Salehi F; et al. (2017): Methodology of the comprehensive program on prevention and control of overweight and obesity in Iranian children and adolescents: the IRANEnding childhood obesity (IRAN-ECHO) program. Int J Prev. Med; 8(1): 107.

UNICEF. United Nations International Children's Emergency Fund (2011): Levels and Trends in Child Mortality. Estimates Developed by the UN Inter-Agency Group for Child Mortality Estimation.

United Nations. (2008): Millennium Development Goals. Department of Public Information. 
World Food Programme (WFP). (2004): School Children Nutrition. WFP, London; 69.

World Food Programme. (2010): http://www.wfp.org/hunger/faqs.

World Health Organization. (2010): Country Cooperation Strategy for WHO and Egypt. WHO Regional Office for the Eastern Mediterranean, Cairo.

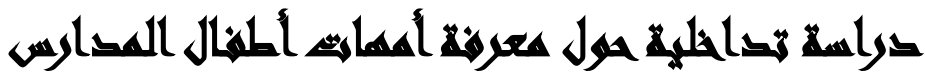

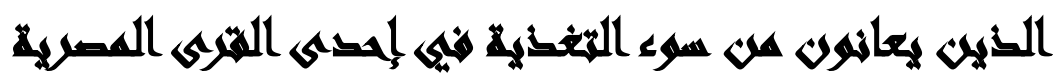

دعاء السيد أحمد(')- هالة إبراهيم عوض الله(؟)- محب كامل الرافعي(؟)

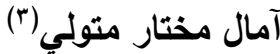

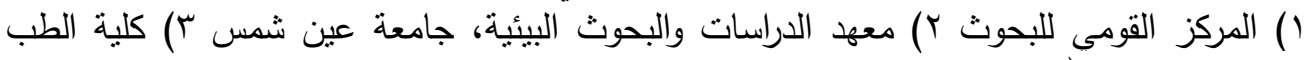

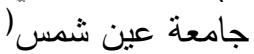

\section{المستخلمع}

الخلفية: يمر أطفال المدارس بتغيرات جسدية وعقلية كبيرة نؤثثر على نموهم وأدائهم المدرسي. يعتبر سوء التغنية لدى الأطفال مصدر قلق كبير في البلدان النامية. الههف من البحث: تحديد التغيير في معرفة أمهات الأطفال في سن المدرسة بقرية العثمانية بمحافظة

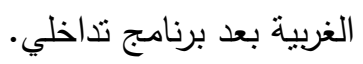

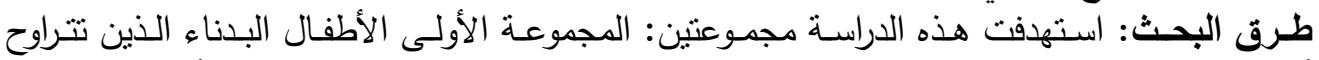

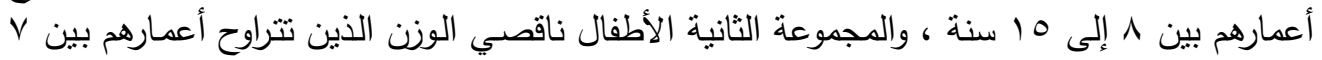

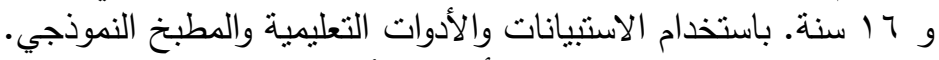

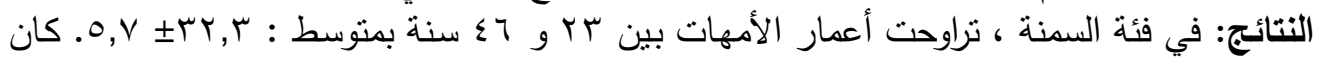

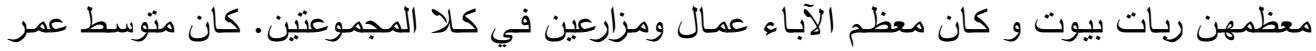

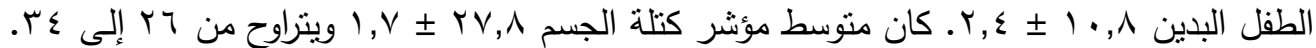

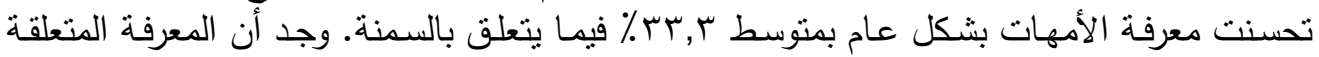

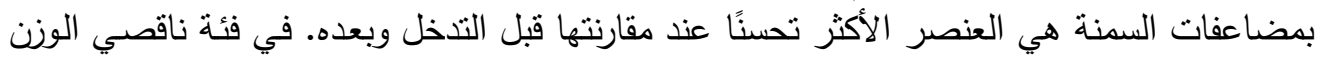


Journal of Environmental Sciences (JES)

Institute of Environmental Studies and Research, Ain Shams University

Doaa E. Ahmed et al.

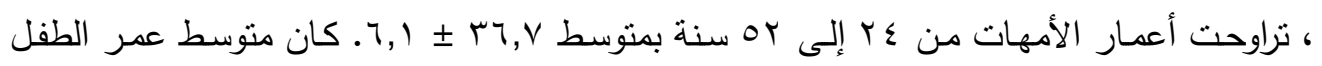

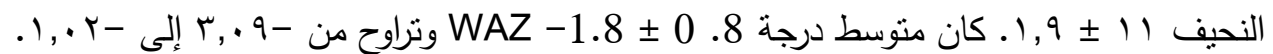

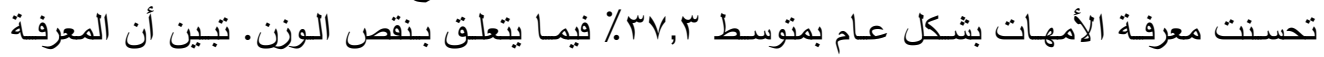

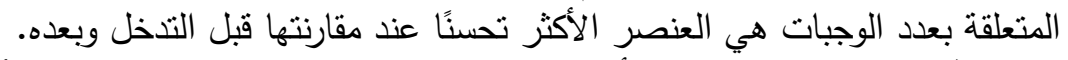
الخلاصة: تشير هذه النتائج إلى أن وضع تدابير تداخلية لتحسين المعرفة في الأمهات ومؤشر كتلة

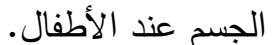
الكلمات الدالة: سوء التغذية، السمنة، نقص الوزن، المعرفة، أطفال المدارس. 